Supporting Information

\title{
Hydrolytically Stable Polyimide Ionomer for Fuel Cell Applications
}

\author{
Naoki Asano, Kenji Miyatake, and Masahiro Watanabe \\ Clean Energy Research Center, University of Yamanashi, \\ 4 Takeda, Kofu 400-8510, Japan
}

\section{Polymerization and Membrane Preparation}

3,3'-Bis(sulfopropoxy)-4,4'-diaminobiphenyl (1.0 $\mathrm{mmol})$, decamethylenediamine (1.0 $\mathrm{mmol})$, triethylamine $(1.5 \mathrm{mmol})$ and $7 \mathrm{~mL}$ of $\mathrm{m}$-cresol were placed in a four-neck round bottomed flask equipped with a magnetic stirring bar and nitrogen inlet. The mixture was stirred at $70{ }^{\circ} \mathrm{C}$ for $30 \mathrm{~min}$. After clear solution was obtained, 1,4,5,8-naphthalene tetracarboxylic dianhydride $(2 \mathrm{mmol})$, benzoic acid $(4 \mathrm{mmol})$ and $6 \mathrm{~mL}$ of $\mathrm{m}$-cresol were added to the mixture. After clear solution was obtained, the mixture was cooled to room temperature. It was stirred for $24 \mathrm{~h}$ under a stream of nitrogen. The mixture was then heated at $175^{\circ} \mathrm{C}$ for $15 \mathrm{~h}$ and at $195{ }^{\circ} \mathrm{C}$ for $3 \mathrm{~h}$. The mixture was poured dropwise into large excess of acetone to precipitate a yellow powder of the product. The product was filtered, washed with acetone and dried at $60{ }^{\circ} \mathrm{C}$ for $12 \mathrm{~h}$ to give the polyimide ionomer in triethylammonium salt form.

The polymer $(0.2 \mathrm{~g})$ was dissolved in $7 \mathrm{~mL}$ of dimethylsulfoxide (DMSO), and then cast onto a flat glass plate. Drying at $80{ }^{\circ} \mathrm{C}$ under reduced pressure gave a crude membrane, which was immersed in ethanol containing $1 \mathrm{~N} \mathrm{HNO}_{3}$ for $12 \mathrm{~h}$. The acidification process was repeated three times followed by washing with pure ethanol. The obtained membrane of $\mathbf{3}$ in acid form was dried under reduced pressure at $80{ }^{\circ} \mathrm{C}$ for $12 \mathrm{~h}$. The ${ }^{1} \mathrm{H}$ NMR spectrum of 3 in DMSO- $d_{6}$ is depicted in the next sheet. 


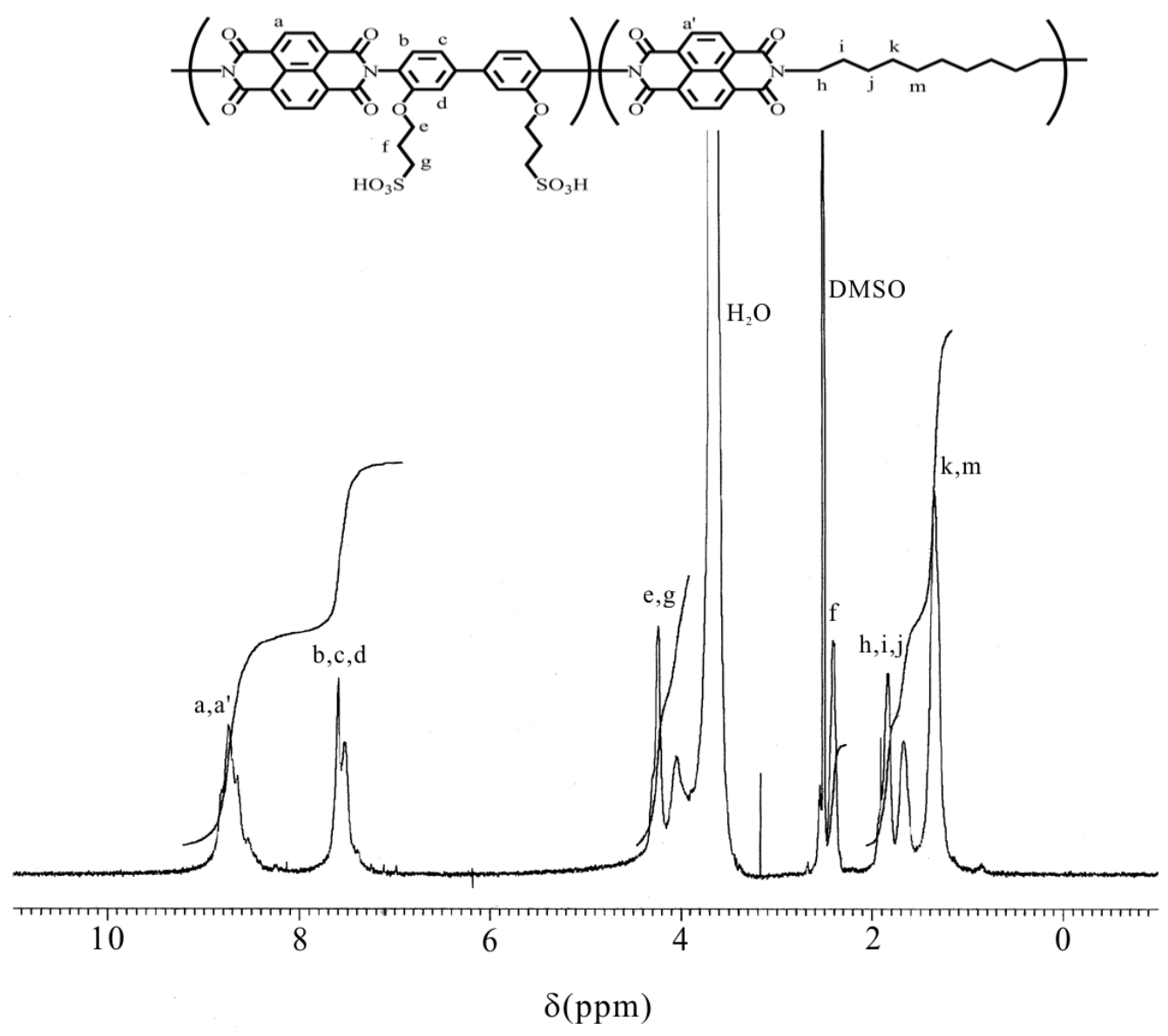

Figure 1S. ${ }^{1} \mathrm{H}$ NMR spectrum of 3 .

\section{Proton Conductivity Measurement}

A four-point-probe conductivity cell with two gold plate outer current-carrying electrodes and two platinum wire inner potential carrying electrodes was fabricated. Membrane samples were cut into strips that were $0.5 \mathrm{~cm}$ wide and $4.5 \mathrm{~cm}$ long, and $50 \mu \mathrm{m}$ thick prior to mounting in the cell. The cell was placed in a stainless steel chamber where the temperature and the humidity were controlled by flowing humidified nitrogen. Impedance measurements were made using Solartron SI1280 electrochemical impedance analyzer. The instrument was used in galvanostatistic mode with an ac current amplitude of $0.005 \mathrm{~mA}$ over a frequency range from 10 to $20000 \mathrm{~Hz}$. 